\title{
Affinity Induced Surface Functionalization of Liposomes Using Cu-Free Click Chemistry
}

Bak, Martin; Jølck, Rasmus Irming; Eliasen, Rasmus; Andresen, Thomas Lars

Published in:

Bioconjugate Chemistry

Link to article, DOI:

10.1021/acs.bioconjchem.6b00221

Publication date:

2016

Document Version

Peer reviewed version

Link back to DTU Orbit

Citation (APA):

Bak, M., Jølck, R. I., Eliasen, R., \& Andresen, T. L. (2016). Affinity Induced Surface Functionalization of Liposomes Using Cu-Free Click Chemistry. Bioconjugate Chemistry, 27(7), 1673-80.

https://doi.org/10.1021/acs.bioconjchem.6b00221

\section{General rights}

Copyright and moral rights for the publications made accessible in the public portal are retained by the authors and/or other copyright owners and it is a condition of accessing publications that users recognise and abide by the legal requirements associated with these rights.

- Users may download and print one copy of any publication from the public portal for the purpose of private study or research.

- You may not further distribute the material or use it for any profit-making activity or commercial gain

- You may freely distribute the URL identifying the publication in the public portal

If you believe that this document breaches copyright please contact us providing details, and we will remove access to the work immediately and investigate your claim 


\title{
Affinity Induced Surface Functionalization of Liposomes using $\mathrm{Cu}$-free Click Chemistry
}

\author{
Martin Bak, Rasmus I. Jølck, Rasmus Eliasen and Thomas L. Andresen*
}

Department of Micro- and Nanotechnology, DTU Nanotech, Centre for Nanomedicine and Theranostics, Technical University of Denmark, Building 423, DK-2800 Kgs. Lyngby, Denmark

\footnotetext{
* Prof. Thomas L. Andresen, E-mail: Thomas.andresen@nanotech.dtu.dk
}

\section{ABSTRACT}

Functionalization of nanoparticles is a key element for improving specificity of drug delivery systems toward diseased tissue or cells. In the current study we report a highly efficient and chemoselective method for postfunctionalization of liposomes with biomacromolecules, which equally well can be used for functionalization of other nanoparticles or solid surfaces. The method exploits a synergistic effect of having both affinity- and covalent anchoring tags on the surface of the liposome. This was achieved by synthesizing a peptide linker system that uses $\mathrm{Cu}$-free strain-promoted click chemistry in combination with histidine affinity tags. The investigation of post-functionalization of PEGylated liposomes was performed with a cyclic RGDfE peptide. By exploring both affinity and covalent tags a $98 \pm 2.0 \%$ coupling efficiency was achieved, even a diluted system showed a coupling efficiency of $87 \pm 0.2 \%$. The reaction kinetics and overall yield were quantified by HPLC. The results presented here opens new possibilities for constructing complex nanostructures and functionalized surfaces.

\section{INTRODUCTION}

Nanoparticle based carrier systems are heavily investigated as therapeutic and diagnostic delivery vectors, and they have the potential to improve clinical practice by offering better diagnosis, treatment and management of human disease. ${ }^{1,2}$ Functionalized nanomaterials for use in drug delivery with targeting ligands on the surface have received considerable attention due to the potential of increasing drug 
1 bioavailability at the diseased site by targeting selective or overexpressed receptors on the target cells. ${ }^{3-5}$

2 Targeting ligands can broadly be classified as proteins (e.g. antibodies and their fragments), nucleic acids (aptamers) or other receptor ligands (e.g. carbohydrates, peptides, and vitamins). A vast number of bioconjugation methods have been reported for functionalization of liposomes and nanoparticles, all of which have their pros and cons. ${ }^{6,7}$ The method developed in this paper uses liposomes as an exemplifying nanomaterial where both covalent and non-covalent functionalization of nanoparticles is utilized.

Post-functionalization of liposomes is typically the method of choice when functionalizing with large and complex ligands such as proteins and antibodies or fragments thereof. This technique ensures the absence of ligand in the interior space of the liposome, thus less ligand is required. Unfortunately, ligand conjugation by post-functionalization can suffer from low yield and large batch-to-batch variation. For some targeting ligands, it is a necessity that they are attached to liposomes by post-functionalization, because larger proteins, e.g. antibodies, are vulnerable to denaturation, hence chemical reactions compatible with the aqueous environment is a prerequisite. Conjugation techniques have until now only been focused on a single attachment point on the liposome surface by either a covalent ${ }^{6,8}$ or non-covalent coupling ${ }^{9-11}$. Cu(I)-catalyzed Huisgen 1,3-dipolar cycloaddition (CuAAC) of azides to terminal alkynes has served as a benchmark for a decade, due to the excellent stability of the formed triazole, excellent orthogonality towards other functional groups and easy accessibility of azide and alkyne tags. While the conventional CuAAC reaction ${ }^{12,13}$ is commonly employed in surface derivatization and polymer synthesis ${ }^{14-16}$, the use of metal catalyst often limits its utilization in biological settings. Copper ions are cytotoxic ${ }^{17}$, can cause DNA degradation ${ }^{18,19}$ and induce protein denaturation ${ }^{20}$ resulting in loss of the native properties of the attached macromolecule. By substituting terminal alkynes with strain-promoted ${ }^{21}$ or electron deficient alkynes ${ }^{22}$, triazole formation can be achieved without the addition of catalyst under ambient conditions without disrupting the function of the immobilized macromolecule. This approach has previously been employed for modification of quantum $\operatorname{dots}^{23}$, liposomes ${ }^{24-26}$, proteins $^{27,28}$ and living cells and organisms $s^{29-31}$. We have previously showed effective coupling of a somastostatin receptor targeting peptide (TATE) to the lipid moiety via strain-promoted alkyne-azide [3+2] cycloaddition (SPAAC). ${ }^{8,32}$ 
1 Recombinant proteins have found widespread use in the growing field of proteomics. Affinity tags are

2 routinely used for fixation of recombinant hybrids to facilitate their purification. In addition to purification 3 and immobilization of biomolecules, they also support a variety of applications such as protein labeling, 4 targeting approaches, 2D crystallization, and biosensing. ${ }^{33-36}$ The parameter-dependent binding affinity of 5 histidine affinity tagged (His-tagged) proteins to nitrilotriacetic acid (NTA) or trisNTA has been explored regarding length of the poly-His-tag, multivalency of NTA moieties, and accessibility of NTA moieties on 7 the surface ${ }^{9,37,38}$. The aim of these studies was to create a highly efficient receptor system. For example, a 8 His-tag containing six histidine-residues have been shown to have binding affinity in the subnanomolar 9 range, while an increase in histidine-residues resulted in a decreased affinity for binding to the divalent transition metal ions $\left(\mathrm{Ni}^{2+}, \mathrm{Zn}^{2+}, \mathrm{Co}^{2+}\right.$ or $\left.\mathrm{Cu}^{2+}\right) .{ }^{39}$ This presents a non-covalent approach to ensure a controlled display of macromolecules on the surface of liposomes. ${ }^{9,37,40}$

We envisioned that liposomes exposing affinity tags in addition to chemically reactive functionalities would aid in the attraction and orientation of the macromolecules thus affecting the kinetic profile and the coupling efficiency of surface conjugation reactions. To test the hypothesis we have investigated PEGylated liposomes with NTA-chelates, strained cyclooctynes and a combination of both at the liposome interface and shown that post-functionalization of His-tagged cyclic RGDfE exposing an azide functionality in close proximity to the His-tag can be induced using this strategy. We believe this general concept seen in Figure 1, exemplified by affinity induced surface functionalization of liposomes, will be highly beneficial when designing new functionalized nanomaterials, especially in highly diluted environments. 


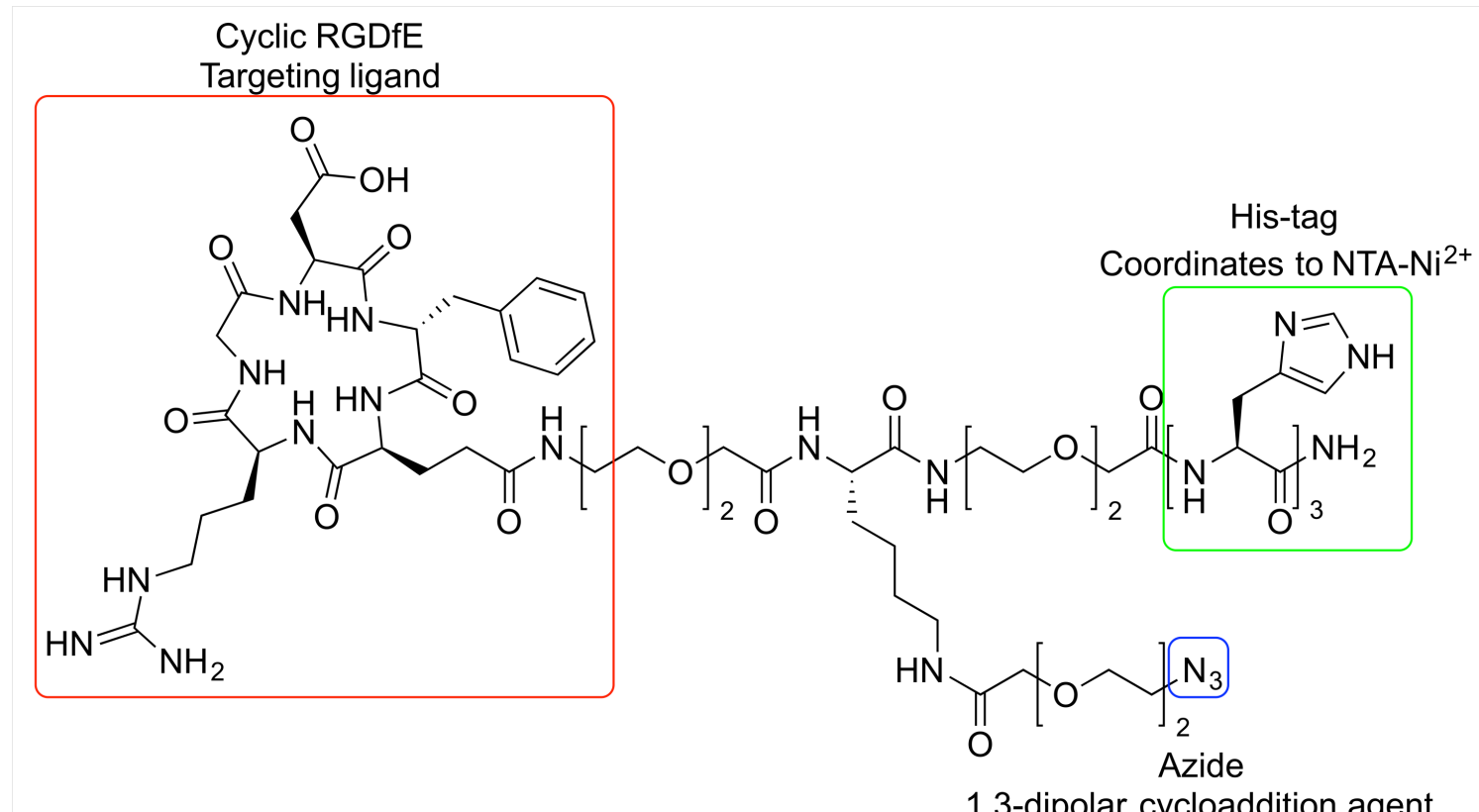

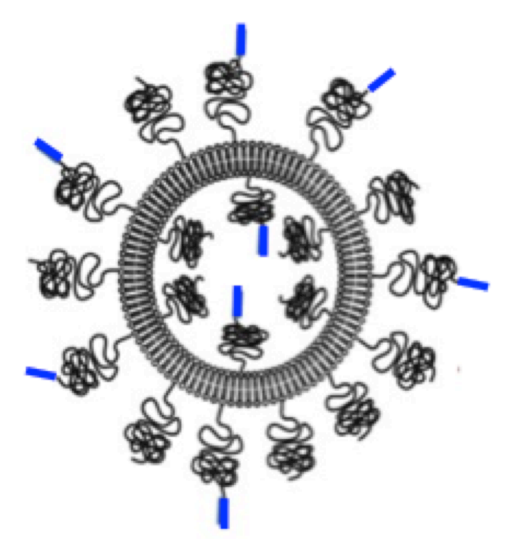

Liposome 1

Strained cyclooctyne Cu-Free Click Chemistry

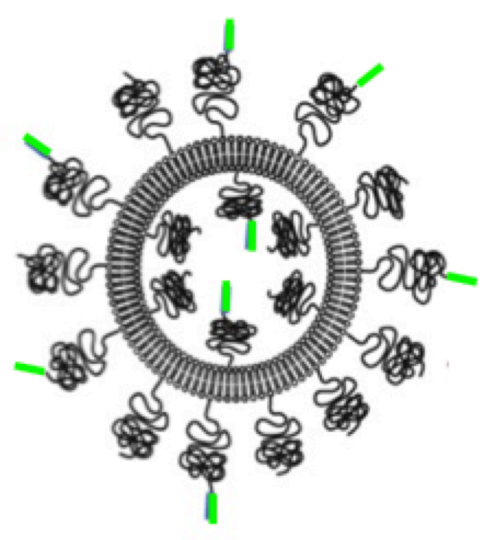

Liposome 2

Chelator

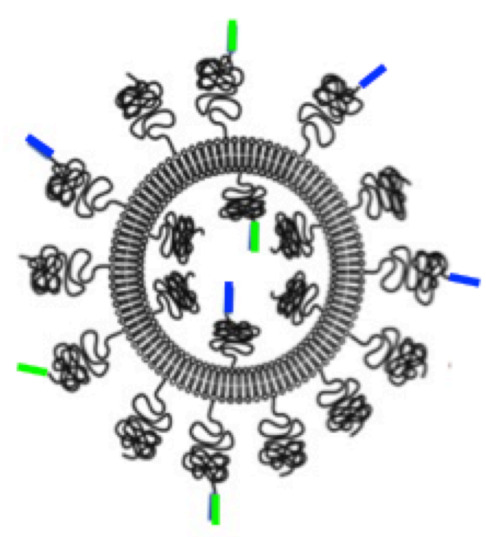

Liposome 3

Both functionalities

Coordinates to $\mathrm{Ni}^{2+}$

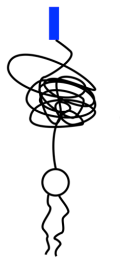

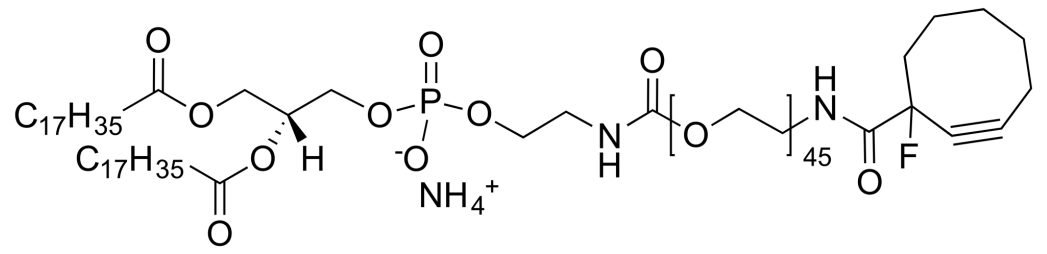

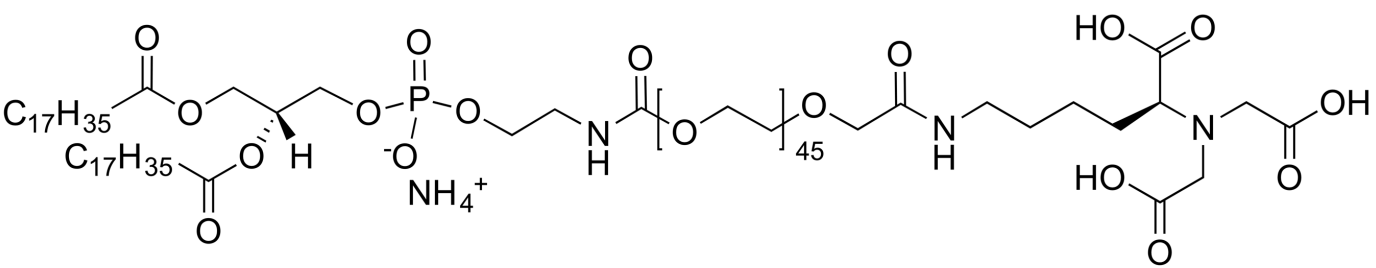

Figure 1. Linker system (4) for post-functionalization of liposomes. Red box: Targeting moiety, c(RGDfE). Blue box: Azide and strained cyclooctyne for SPAAC coupling. Green box: His $_{3}$-tag and nitrilotriacetic acid (NTA) for formation of hexa-coordinated nickel complex. 
Scheme 1. Synthesis of the c(RGDfE) functionalized peptide linker (3 and 4)

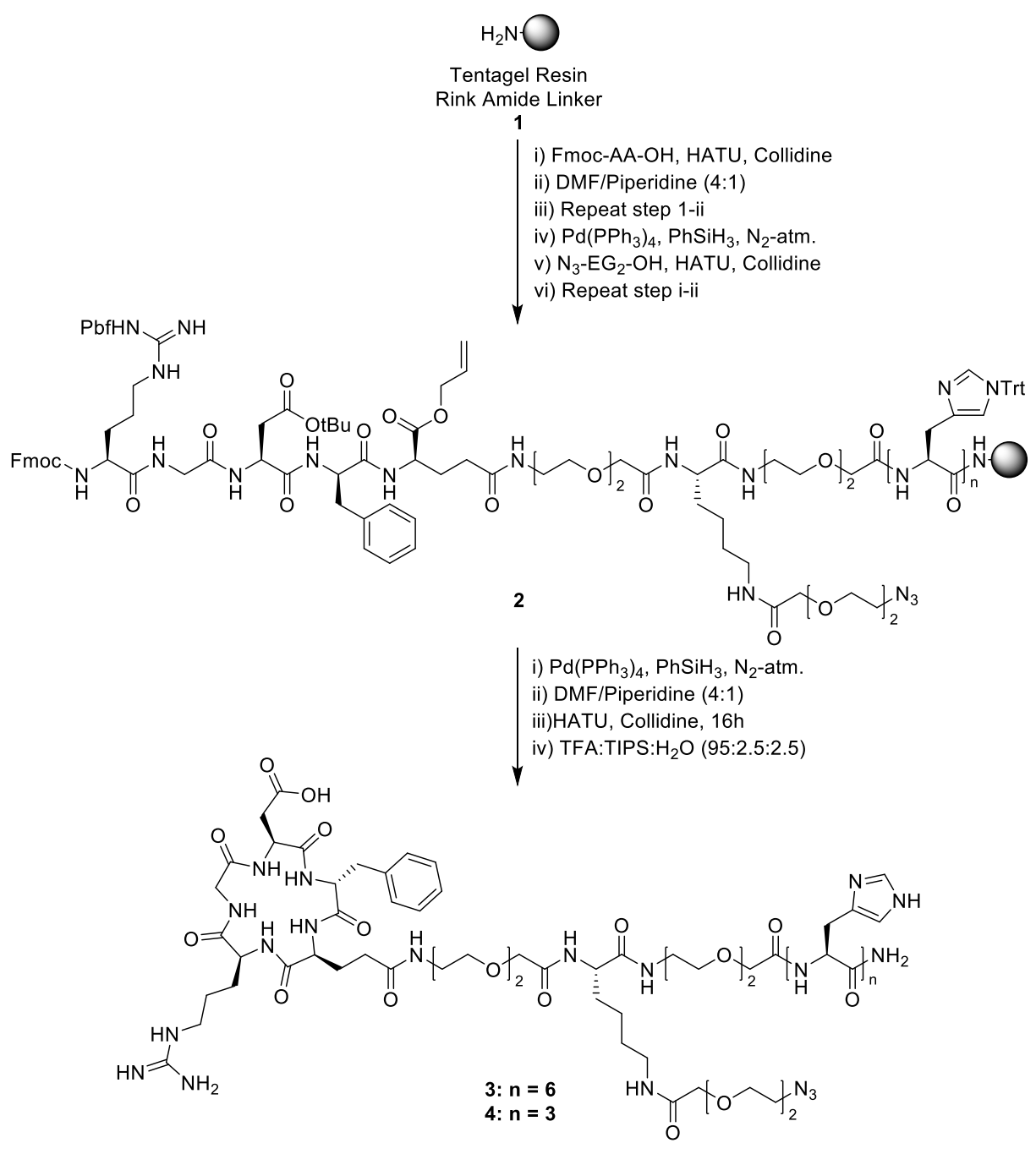

6 Synthesis and Characterization. The c(RGDfE) functionalized linker peptides 3 and $\mathbf{4}$ were prepared using

7 a SPPS strategy as shown in Scheme 1. Intramolecular cyclization was achieved using an orthogonal 8 protection group scheme. ${ }^{41}$ Peptides 3 and $\mathbf{4}$ were cleaved from the solid support using TFA:TIPS: $\mathrm{H}_{2} \mathrm{O}$ and 9 subsequently purified by HPLC. Laser-induced reduction of the azido functionality to the corresponding amine was observed during MALDI-TOF MS analysis as previously observed by Budyka et al. ${ }^{42}$. The intact azido functionality was confirmed by FT-IR analysis at $2112 \mathrm{~cm}^{-1}$. A His 6 -tag was successfully synthesized 
and isolated, but a large degree of aggregation was observed for this molecule in aqueous solutions. This would presumably create complications in the later liposome study. A His 3 -tag was made, which was sufficient to create the coupling to the chelate of NTA-Ni ${ }^{2+}\left(K_{\mathrm{D}}=2.23 \times 10^{-6} \mathrm{M}\right)^{37}$ and limit the aggregation. This was also in correspondence with a previous study by Knecht et al. ${ }^{37} \cdot{ }^{10}$

In order to formulate liposomes exposing the appropriate chemical functionalities at the distal end of the PEG-layer, the desired functionalized PEGylated phospholipids were synthesized in solution from either DSPE-PEG $2000-\mathrm{NH}_{2}$ or DSPE-PEG $2000-\mathrm{NHS}$. The phospholipid with the strained cyclooctyne at the distal end of the polymer was synthesized by acylating DSPE-PEG $\mathrm{P}_{2000}-\mathrm{NH}_{2}$ with 1-fluorocyclooct-2-ynecarboxylic acid. ${ }^{32}$ 1-Fluorocyclooct-2-ynecarboxylic acid was synthesized as described elsewhere. ${ }^{43}$ DSPE-PEG $_{2000^{-}}$ NTA was synthesized in a single acylation step between DSPE-PEG ${ }_{2000}-$ NHS and NTA.

Three different compositions of liposomes were prepared in order to investigate the effect on surface conjugation efficiency induced by having an affinity tag present on the liposomal surface. A concentrated TRIS/HCl buffer was used to minimize non-specific electrostatic interactions when using the negatively charged Ni-NTA complex. ${ }^{44}$ Formed liposomes were characterized by DLS and $\zeta$-potential (Table 1), and stored at $5{ }^{\circ} \mathrm{C}$ until use. Post-functionalization investigations were carried out by adding the required components for the individual reactions (e.g. $\mathrm{Ni}^{2+}$ for the His-tag affinity coupling), followed by addition of 4 in $\mathrm{CH}_{3} \mathrm{OH}$. Liposome integrity was tested in different concentrations in the final solvent mixture by DLS to ensure their stability in the given reaction environment. The $\mathrm{CH}_{3} \mathrm{OH}$ concentration of $1.5-3 \%$ was not found to affect the stability of the liposomes. All reactions were monitored for $72 \mathrm{~h}$ by HPLC using UV/VISdetection. The conjugation efficiency was calculated based on the AUC for $\mathbf{4}$ and the DSPE-PEG $2000^{-}$ c(RGDfE) conjugate. Triplicates of all reactions were carried out to ensure reproducibility and elucidate the variance of the post-functionalization reactions at the liposomal surfaces.

Table 1. DLS and Zeta-potential measurements of the liposome formulations

\begin{tabular}{ccc}
\hline Entry \# & DLS & Zeta-potential \\
\hline $\mathbf{1}$ & $115.2 \pm 0.9 \mathrm{~nm}$ & $-4.02 \pm 2.85 \mathrm{mV}$ \\
$\mathbf{2}$ & $115.8 \pm 1.7 \mathrm{~nm}$ & $-9.68 \pm 2.56 \mathrm{mV}$ \\
$\mathbf{3}$ & $112.1 \pm 0.7 \mathrm{~nm}$ & $-2.22 \pm 3.06 \mathrm{mV}$ \\
\hline
\end{tabular}


1 Coupling of 4 to preformed liposomes by SPAAC. The efficiency of the individual conjugation techniques

2 was first addressed. Coupling of 4 to preformed liposomes via SPAAC reaction was investigated using the

3

4

5

DSPE-PEG ${ }_{2000}$-cyclooctyne (5) and azide functionalized 4. The combined data acquisition gave the conclusive result that the SPAAC chemistry proceeds in good yield, with a mean conversion of $83 \pm 1.5 \%$ after $72 \mathrm{~h}$ at $\mathrm{rt}$ (Figure 2) in good correlation with previous work by Feldborg et al. ${ }^{32}$. Presence of $\mathrm{Ni}^{2+}$ during the SPAAC reaction did not alter the reaction kinetics or conversion degree (data not shown).

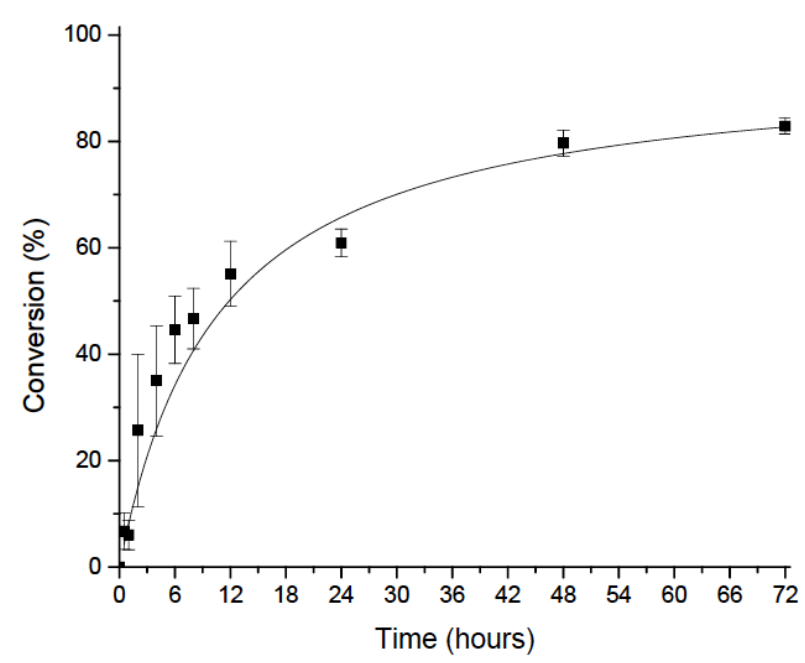

Figure 2. Coupling efficiencies of 4 to DSPE-PEG2000-cyclooctyne (5) by SPAAC chemistry at the liposome surface (Liposome 1). All values are means $\pm \operatorname{SEM}(n=3)$.

Complexation of 4 to preformed liposomes by His $_{3}$-tag. Complex-formation to preformed liposomes via His-tag was investigated using the DSPE-PEG $2000-\mathrm{NTA}(\mathbf{6})$ and $\mathrm{His}_{3}$-tag functionalized 4. Reactions were carried out using two different amount of $\mathrm{Ni}^{2+}$ ( 1 or 10 equiv.) to investigate how the $\mathrm{Ni}^{2+}$-concentration affected the complex formation with 4 . No notable difference in using 1 or 10 equiv. of $\mathrm{Ni}^{2+}$ was observed, hence, 1 equiv. was used onwards. The dissociation constants of four Ni-NTA complexes have been taken into consideration to verify the affinity based complex formation between the liposome and targeting ligand $\left(\mathrm{Ni}^{2+}\right.$-His-tag complex: $K_{\mathrm{D}} \approx 10^{-6} \mathrm{M}, \mathrm{Ni}^{2+}$-Imidazole: $K_{\mathrm{D}}=9.8 \times 10^{-4} \mathrm{M}, \mathrm{Ni}^{2+}-\mathrm{NTA}: K_{\mathrm{D}}=1.8 \times 10^{-11} \mathrm{M}$ and $\mathrm{Ni}^{2+}$-EDTA complex: $\left.K_{\mathrm{D}}=4.0 \times 10^{-19} \mathrm{M}\right)^{45-48}$. Firstly, the reversibility of the complex was tested by competitive complexation to determine the stability of the complex. Trans-complexation by addition of acetic acid resulted in recovery of $\mathbf{4}$ as analyzed by HPLC. Furthermore, in order to confirm the NTA-Ni ${ }^{2+}-$ 
1 His-tag complex formation, imidazole was added to the Ni-NTA complex prior to addition of 4, thus

2 hindering the coupling of the His-tag. Because the $K_{\mathrm{D}}$ of the NTA-Ni ${ }^{2+}$-Imidazole complex is larger than $K_{\mathrm{D}}$

3 for the NTA-Ni ${ }^{2+}-\mathrm{His}_{3}$-tag complex, the $\mathrm{His}_{3}$-tag will still associate to the Ni-NTA complex but to a less

4 extend than previously observed. Hindering the Ni-NTA complexation with imidazole resulted in only

5 approximately $10 \%$ association of 4 after $42 \mathrm{~h}$. In comparison, the triplicate data showed a mean complex efficiency of $72 \pm 2.0 \%$ after $72 \mathrm{~h}$ (Figure 3). This implies that imidazole is able to slow down the

7 coordination degree significantly by competitive binding to the NTA-Ni ${ }^{2+}$-moiety on the liposomal surface.

8 Combined, the obtained data confirms that NTA-tags efficiently associate with His-tag ligands on the

9 liposome surface and that the complexation is reversible as shown by trans-complexation.

10

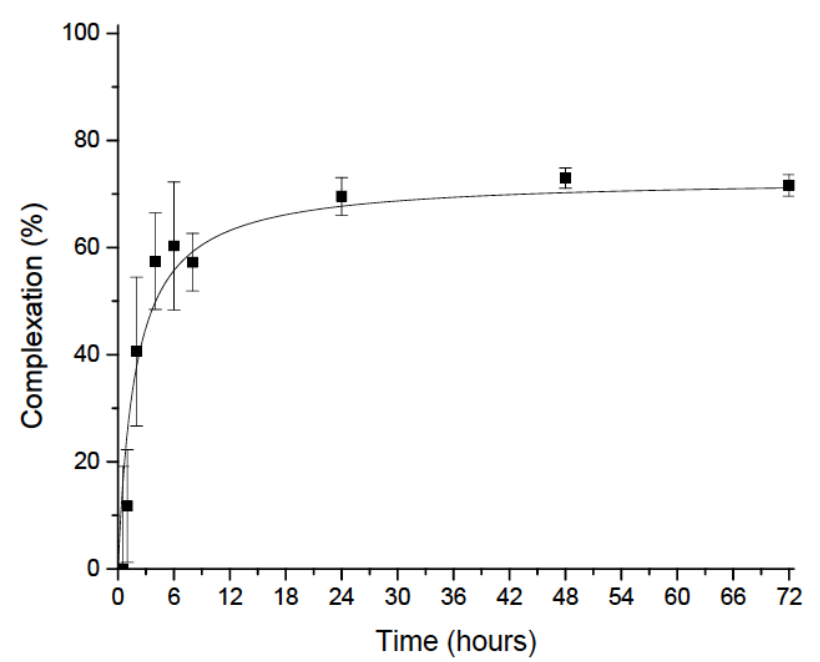

Figure 3. Complexation efficiencies of $\mathbf{4}$ to DSPE-PEG2000-NTA-Ni ${ }^{2+}(\mathbf{6})$ by a complex-formation via the $\mathrm{His}_{3}$-tag at the liposome surface (Liposome 2). All values are means $\pm \operatorname{SEM}(n=3)$.

Affinity induced covalent coupling of 4 to liposomes. The liposome composition with both NTA (1 mol\%) and cyclooctyne ( $1 \mathrm{~mol} \%)$ moieties was incubated with $\mathrm{Ni}^{2+}$ (1 equiv.) and was subsequently added 4 . The progression of the affinity induced covalent coupling of $\mathbf{4}$ was monitored by HPLC. The complexation $\left(\mathrm{NTA}-\mathrm{Ni}^{2+}-\mathrm{His}_{3}\right.$-tag) was disrupted by addition of acetic acid to aliquots after $72 \mathrm{~h}$, however, no change in AUC for the coupled product was observed. This confirmed that $\mathbf{4}$ is covalently attached to the liposome surface by triazole formation. Comparison of the conjugation studies of the SPAAC coupling versus the SPAAC reaction via the affinity $\mathrm{His}_{3}$-tag shows that the $\mathrm{His}_{3}$-tag is able to increase the coupling efficiency 
1 (Figure 4). The mean conjugation of 4 by a SPAAC coupling was $83 \pm 1.5 \%$ after $72 \mathrm{~h}$ whereas the pure

2 affinity based association of $\mathrm{His}_{3}$-tag was $72 \pm 2.0 \%$. Interestingly, the fact is that the mean conjugation of 3 the combined system was significantly better by $98 \pm 2.0 \%$ after $72 \mathrm{~h}$, which can be explained by the higher 4 local concentration of the targeting ligand at the liposomal surface due to the presence of the affinity tag. The 5 combined data acquisition supports that the $\mathrm{His}_{3}$-tag having a promoting effect on the SPAAC-coupling on the surface of preformed liposomes (Figure 4).

7 In order to validate this observation and further investigate the difference between the SPAAC-coupling 8 versus the $\mathrm{His}_{3}$-tag induced SPAAC-coupling surface functionalization of liposomes exposing both NTA (1 mol\%) and cyclooctyne (1 mol\%) moieties with 4 in highly diluted conditions was investigated.

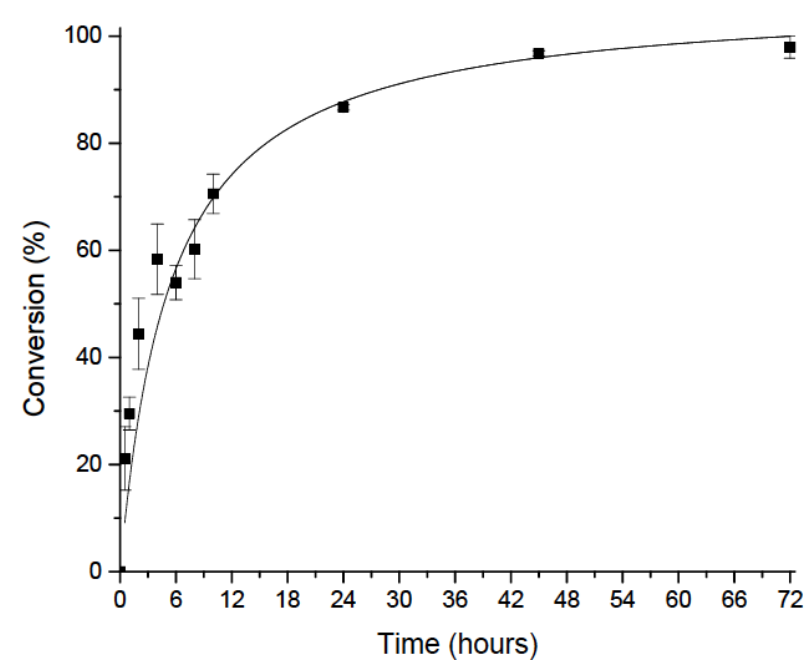

Figure 4. Coupling efficiencies of 4 to the liposome surface by SPAAC chemistry via affinity NTA-Ni ${ }^{2+}-\mathrm{His}_{3}$-complex at the liposome surface (Liposome 3). All values are means $\pm \operatorname{SEM}(n=3)$.

Dilution test of conjugating 4 to preformed liposomes. Next we investigated the ligand conjugation under diluted conditions (diluted 5 fold) to investigate the effects of the affinity-based conjugation to the functionalized liposome surface. The reaction kinetics for the covalent coupling will decrease in the dilute system and the affinity complexation effect will presumably be more pronounced. The reaction kinetics decreased as expected in comparison to the study done under more concentrated conditions (Figure 5). The 
1 liposome formulation with the SPAAC-moiety showed a coupling efficiency of $58 \pm 2.2 \%$ after $72 \mathrm{~h}$,

2 whereas the combined SPAAC and $\mathrm{His}_{3}$-tag system showed a coupling efficiency of $87 \pm 0.2 \%$ after $72 \mathrm{~h}$.

3 The increased difference in coupling efficiency from $15-29 \%$ between concentrated and dilute conditions,

4 respectively, shows the potential of using affinity-based complexation followed by covalent conjugation for

5 functionalizing liposomes.

6

7

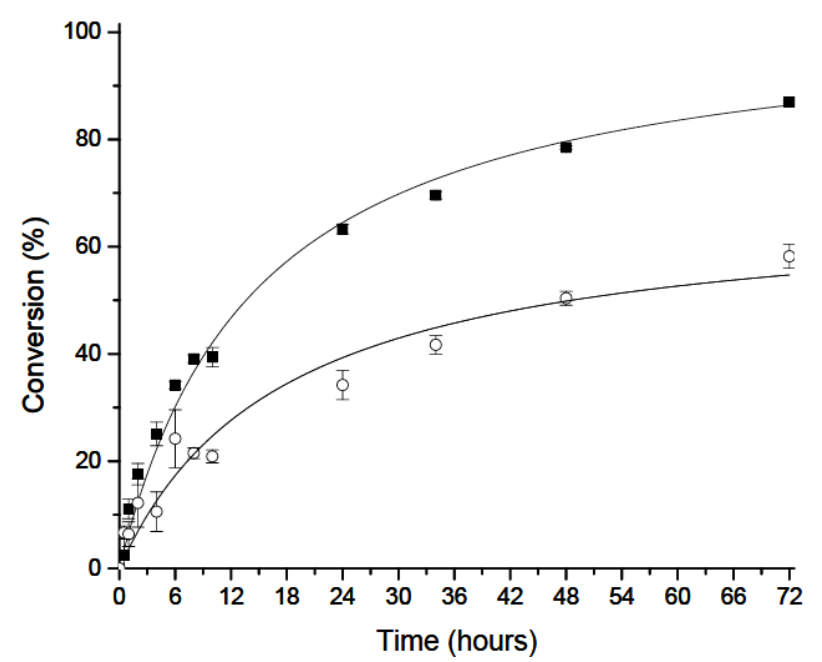

Figure 5. Comparison of the diluted coupling efficiency study: Coupling of DSPE-PEG2000-cyclooctyne (5) and the peptide linker (4) to the liposome surface by SPAAC chemistry (०). Coupling efficiencies of 4 to the liposome surface by SPAAC chemistry via affinity NTA-Ni ${ }^{2+}-\mathrm{His}_{3}$-complex at the liposome surface $(\mathbf{\bullet})$. All values are means $\pm \mathrm{SEM}(\mathrm{n}$ $=3)$.

Table 2. Overview of the yields in the liposomal post-functionalization study determined by analytical HPLC

\begin{tabular}{ccc}
\hline Entry \# & $\mathbf{R}_{\mathbf{1}}$ & Yields after $\mathbf{7 2} \mathbf{~ h}$ \\
\hline $\mathbf{1}$ & SPAAC & $83 \pm 1.5 \%$ \\
$\mathbf{2}$ & $\mathrm{His}_{3}-\mathrm{Ni}^{2+}$-NTA-tag & $72 \pm 2.0 \%$ \\
$\mathbf{3}$ & SPAAC via His ${ }_{3}-\mathrm{Ni}^{2+}$-NTA-tag & $98 \pm 2.0 \%$ \\
$\mathbf{4}$ & Diluted SPAAC & $58 \pm 2.2 \%$ \\
$\mathbf{5}$ & Diluted SPAAC via $\mathrm{His}_{3}-\mathrm{Ni}^{2+}$-NTA-tag & $87 \pm 0.2 \%$ \\
\hline
\end{tabular}

\section{CONCLUSION}

In conclusion, a conceptual new approach has been described for effectively post-functionalizing liposomes.

It has been shown that it is possible to induce a covalent coupling via a synergetic effect with an affinity tag, see Table 2. The $\mathrm{His}_{3}$-tag in the peptide linker system, 4, is able to improve the reaction kinetics of the 
SPAAC chemistry. This presumably happens through an up-concentration at the interface of the liposome. The conjugation technique is bioorthogonal and chemoselective to the functional groups in most relevant ligands such as proteins and aptamers.

The mean conjugation efficiency of 4 by a SPAAC coupling was $83 \pm 1.5 \%$ after $72 \mathrm{~h}$ and $72 \pm 2.0 \%$ for the $\mathrm{His}_{3}$-tag affinity complex-formation. The combined system was significantly faster and gave a total conjugation efficiency of $98 \pm 2.0 \%$ after $72 \mathrm{~h}$. This is a $15 \%$ improvement relative to the SPAAC coupling reaction, but also provides a method that would not require post-conjugation purification of unbound ligand. This is presumably due to favorable interactions between the liposome surface and the $\mathrm{His}_{3}$-tag, which results in up-concentration of $\mathbf{4}$ at the liposome surface and thereby increased coupling efficiency. The symbiotic effect of the dual coupling setup was further verified in a dilution test were the difference in conjugation efficiency increased by $29 \%$.

The findings described are useful for future post-functionalization designs not only for liposomes but also for other nanoparticles. This linker system has the potential to improve the post-functionalization of large and sterically hindered target molecules, such as antibodies or fragments hereof.

\section{EXPERIMENTAL PROCEDURES}

\section{Materials}

All chemicals were purchased from Sigma-Aldrich Inc. (Broendby, Denmark) unless otherwise stated. 1,2distearoyl-sn-glycero-3-phosphocholine (DSPC), 1,2-distearoyl-sn-glycero-3-phosphoethanolamine(polyethylene glycol) ${ }_{2000} \quad\left(\right.$ DSPE-PEG $\left._{2000}\right), \quad$ 1,2-distearoyl-sn-glycero-3-phosphoethanolamine-N[amino(polyethylene glycol) $\left.)_{2000}\right] \quad\left(\mathrm{DSPE}_{2} \mathrm{PEG}_{2000}-\mathrm{NH}_{2}\right), \quad$ and 1,2-distearoyl-sn-glycero-3phosphoethanolamine-N-[succinyl(polyethylene glycol) ${ }_{2000}$ (ammonium salt) (DSPE-PEG $2000-\mathrm{NHS}$ ) were purchased from Avanti Polar Lipids Inc. (Alabama, USA). O-(7-Azabenzotriazol-1-yl)- $N, N, N^{\prime}, N^{\prime}-$ tetramethyluronium hexafluorophosphate (HATU), Tentage ${ }^{\circledR}$ Rink Amide Resin, 2-chlorotrityl resin and all Fmoc protected amino acids used for the solid phase peptide synthesis were purchased from GL Biochem (Shanghai, China). All chemicals and reagents were of analytical grade and used without further purification. 


\section{Instrumentation}

Reactions were monitored by thin layer chromatography (TLC); visualization was carried out by UV-light exposure $(254 \mathrm{~nm})$ and $\mathrm{KMnO}_{4}$-stain. Chromatography refers to open column chromatography on silica gel. Analytical reversed-phase high-performance liquid chromatography (RP-HPLC) was performed on a Gilson HPLC (Gilson Valvemate, UV/VIS-155, 321 Pump, 234 Auto injector) or Waters LC/MS (2695 HPLC system, $2998 \mathrm{UV} / \mathrm{VIS}, 3100 \mathrm{ZQ}$ single quadrupole MS with ESI) by employing an $\mathrm{XBridge}^{\mathrm{TM}} \mathrm{C}_{18} 5 \mu \mathrm{m}$ $(4.6 \times 150 \mathrm{~mm})$, XBridge $^{\mathrm{TM}} \mathrm{C}_{18} 3.5 \mu \mathrm{m}(2.1 \times 50 \mathrm{~mm})$ or a Waters $\mathrm{XTerra}^{\circledR} \mathrm{C}_{8} 5 \mu \mathrm{m}(4.6 \times 150 \mathrm{~mm})$ column. Semi-preparative HPLC was performed on a Waters Semi-preparative HPLC equipped with a Waters 600 Pump \& Controller and a Waters 2489 UV/VIS Detector using a Knauer Eurosphere 100-5 $\mathrm{C}_{18}(20 \times 250 \mathrm{~mm})$ column or a Waters XTerra ${ }^{\circledR} \mathrm{C}_{8} 5 \mu \mathrm{m}(19 \times 150 \mathrm{~mm})$ column. HPLC Eluent A consisted of a $5 \% \mathrm{CH}_{3} \mathrm{CN}$ aqueous solution with $0.1 \%$ trifluoroacetic acid (TFA); HPLC Eluent B consisted of $0.1 \% \mathrm{TFA}$ in $\mathrm{CH}_{3} \mathrm{CN}$. Preparative HPLC analysis was monitored using UV/VIS detection at 220/280 $\mathrm{nm}$. NMR spectra were recorded on a Varian Mercury $400 \mathrm{MHz}$ Spectrometer. ${ }^{1} \mathrm{H}$ and ${ }^{13} \mathrm{C}$ NMR were recorded at 400 - and 100 $\mathrm{MHz}$, respectively. Chemical shifts $(\delta)$ are reported in parts per million (ppm) relative to the solvent's signal peak. Mass spectra were recorded on a Bruker Reflex IV MALDI-TOF Spectrometer using 2,5dihydroxybenzoic acid (DHB) spiked with sodium trifluoroacetate in $\mathrm{CH}_{3} \mathrm{OH}$ as matrix. FT-IR was recorded neat on a Perkin Elmer Instruments Spectra One FT-IR Spectrometer. Dynamic light scattering (DLS) and $\zeta$ potential measurements were performed on a Brookhaven Instruments Corporation ZetaPALS $\zeta$-potential analyzer. Phosphorous analysis was measured by ICP-MS performed on a Dionex ${ }^{\mathrm{TM}}$ ICS- $5000^{+}$system (Thermo Scientific ${ }^{\mathrm{TM}}$, Dreieich, Germany).

\section{Synthesis}

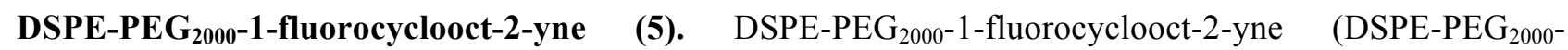
cyclooctyne) was synthesized as previously described by Jølck et al. ${ }^{24}$ and isolated as a white powder. MALDI-TOF MS (m/z): Calc. mass $[\mathrm{M}+\mathrm{H}]^{+}: 2967.9 \pm \mathrm{n} \times 44.0$; found mass $[\mathrm{M}+\mathrm{H}]^{+}: 2968.3 \pm \mathrm{n} \times 44.0 .{ }^{1} \mathrm{H}-$ NMR (400MHz, CDCl3): $\delta 6.83$ (bs, 1H), 5.93 (bs, 1H), 5.22-5.16 (m, 1H) , 4.35-4.01 (m, 10H), 
3.95-3.89 (m, 2H), $3.62(\mathrm{bs}, 164 \mathrm{H}), 3.48-3.36(\mathrm{~m}, 6 \mathrm{H}), 2.32-2.23(\mathrm{~m}, 6 \mathrm{H}), 1.71-1.49(\mathrm{~m}, 6 \mathrm{H}), 1.23(\mathrm{bs}, 56 \mathrm{H})$, $0.85(\mathrm{t}, \mathrm{J}=6.6 \mathrm{~Hz}, 6 \mathrm{H})$. FT-IR: $v\left(\mathrm{~cm}^{-1}\right) 3445.3,2918.2,2851.4,1741.6,1648.9,1104.6$.

DSPE-PEG ${ }_{2000}$-NTA (6). $N_{o}, N_{\alpha}$-Bis(carboxymethyl)-L-lysine $(9.1 \mathrm{mg}, 34.6 \mu \mathrm{mol})$ and triethylamine $(48 \mu \mathrm{L}$, $0.35 \mathrm{mmol})$ in anhydrous dimethylformamide $(1.0 \mathrm{~mL})$ were added to a flame dried flask containing DSPE$\mathrm{PEG}_{2000}$-NHS $(20.7 \mathrm{mg}, 6.9 \mu \mathrm{mol})$ in anhydrous $\mathrm{CH}_{2} \mathrm{Cl}_{2}(1.0 \mathrm{~mL})$ under argon atmosphere and with reaction molecular sieves (4 $\AA$ ). The reaction was stirred at $\mathrm{rt}$ for $15 \mathrm{~h}$ after which the solvent was removed in vacuo and the product purified by semi-preparative HPLC employing a Waters XTerra ${ }^{\circledR} \mathrm{C}_{8} 5 \mu \mathrm{m}(10 \mathrm{x} 150 \mathrm{~mm})$ column. Eluent: (A) $5 \% \mathrm{CH}_{3} \mathrm{CN}+0.1 \%$ TFA in $\mathrm{H}_{2} \mathrm{O}$, (B) $0.1 \%$ TFA in $\mathrm{CH}_{3} \mathrm{CN}$. Gradient profile: Linear gradient from $20 \% \mathrm{~B}$ to $100 \% \mathrm{~B}$ over $20 \mathrm{~min}$. Flow rate: $7 \mathrm{~mL} / \mathrm{min}$. UV/VIS monitoring at 220 and 280 nm. Column temperature: $40{ }^{\circ} \mathrm{C}$. DSPE- $\mathrm{PEG}_{2000}-\mathrm{NTA}$ was isolated as a broad homogenous peak with retention time of $10.8 \mathrm{~min}$. The solvent was removed in vacuo and the product lyophilized from a mixture of $\mathrm{H}_{2} \mathrm{O}$ and $\mathrm{CH}_{3} \mathrm{CN}$ to give a white fluffy powder $(9.1 \mathrm{mg}, 40 \%$, purity $>98 \%)$. MALDI-TOF MS (m/z): Calc. mass $[\mathrm{M}+\mathrm{H}]^{+}: 3212.9 \pm \mathrm{n} \times 44.0$; found mass $[\mathrm{M}+\mathrm{H}]^{+}: 3213.1 \pm \mathrm{n} \times 44.0 .{ }^{1} \mathrm{H}-\mathrm{NMR}\left(400 \mathrm{MHz}, \mathrm{CDCl}_{3}\right): \delta 5.17$ (m, 1H), $4.07(\mathrm{~m}, 2 \mathrm{H}), 4.01-3.69(\mathrm{~m}, 4 \mathrm{H}), 3.54(\mathrm{~m}, 180 \mathrm{H}), 3.51-3.46(\mathrm{~m}, 4 \mathrm{H}), 3.42(\mathrm{t}, 2 \mathrm{H}), 3.36(\mathrm{t}, 1 \mathrm{H})$, 3.17-3.09 (m, 4H), 2.27-2.19 (m, 4H), 2.14-2.09 (m, 4H), $1.80(\mathrm{~m}, 2 \mathrm{H}), 1.66$ (f, 2H), 1.61-1.30 (m, 8H), 1.20 (m, 58H), $0.81(\mathrm{t}, 6 \mathrm{H})$. FT-IR: $v\left(\mathrm{~cm}^{-1}\right) 3337.3,2918.5,2852.1,1696.9,1106.2$.

c(RGDfE)-EG $-\mathbf{E}-\mathbf{K}\left(\mathbf{E G}_{2}-\mathbf{N}_{3}\right)-\mathbf{E G}_{\mathbf{2}}-\mathrm{His}_{3}$ (4). The peptide linker was synthesized by solid-phase peptide synthesis (SPPS) on a Tentagel ${ }^{\circledR}$ resin (loading $0.25 \mathrm{mmol} / \mathrm{g}$ ) with a Rink amide linker by standard Fmoc methodology. Each coupling was performed using 4.0 equiv. Fmoc protected amino acid, 3.95 equiv. HATU and 8 equiv. 2,4,6-collidine in DMF. Deprotection of the Fmoc group was carried out using $20 \%$ piperidine in DMF for $2 \times 5$ min. Completion of each coupling and deprotection step was monitored by the Kaiser test. The first step was synthesis of Fmoc-EG $2-\mathrm{K}(\mathrm{Alloc})-\mathrm{EG}_{2}-(\mathrm{H}(\mathrm{Trt}))_{3}$-resin. Removal of Alloc protection group on the lysine residue was achieved by washing the resin with dry $\mathrm{CH}_{2} \mathrm{Cl}_{2}(5 \times 30 \mathrm{sec})$ under $\mathrm{N}_{2}$-atmosphere. A solution of $\mathrm{PhSiH}_{3}$ (24 equiv.) in dry $\mathrm{CH}_{2} \mathrm{Cl}_{2}$ was mixed with the resin. A dispersion of $\mathrm{Pd}\left(\mathrm{PPH}_{3}\right)_{4}(0.5$ equiv.) in dry $\mathrm{CH}_{2} \mathrm{Cl}_{2}$ was added and stirred for 10 min with $\mathrm{N}_{2}$-atmosphere. The peptide was washed with 
$1 \mathrm{CH}_{2} \mathrm{Cl}_{2}(8 \times 30 \mathrm{sec})$ and the process was repeated. ${ }^{49} \mathrm{~N}_{3}-\mathrm{EG}_{2}-\mathrm{COOH}$ was coupled to the deprotected lysine side

2 chain as described above. The couplings where continued at the N-terminal end with the linear peptide sequence Fmoc-R(Pbf)-G-D( $\left.{ }^{\mathrm{B}} \mathrm{Bu}\right)-\mathrm{f}-\mathrm{E}-\mathrm{OAll}$. Allyl deprotection on the glutamic acid residue was achieved using the same procedure like for deprotection of the lysine residue, but repeated twice. ${ }^{49}$ The intramolecular cyclization was achieved by deprotecting Fmoc followed by standard HATU coupling procedure for $16 \mathrm{~h}$. The resin was cleaved with TFA:triisopropylsilane(TIPS): $\mathrm{H}_{2} \mathrm{O}(95: 2.5: 2.5)$ for $2 \mathrm{~h}$. Final purification was achieved by semi-preparative HPLC by employing a Waters XTerra ${ }^{\circledR} \mathrm{C}_{8} 5 \mu \mathrm{m}(19 \mathrm{x} 150 \mathrm{~mm})$ column. Eluent: (A) $5 \% \mathrm{CH}_{3} \mathrm{CN}+0.1 \%$ TFA in $\mathrm{H}_{2} \mathrm{O}$, (B) $0.1 \% \mathrm{TFA}$ in $\mathrm{CH}_{3} \mathrm{CN}$. Gradient profile: Linear gradient from $0 \%$ B to $100 \%$ B over $20 \mathrm{~min}$. Flow rate: $17 \mathrm{~mL} / \mathrm{min}$. Solvent for injection: $\mathrm{H}_{2} \mathrm{O} /$ acetic acid (4:1). The solvent was removed in vacou and the product lyophilized from a mixture of $\mathrm{H}_{2} \mathrm{O}$ and $\mathrm{CH}_{3} \mathrm{CN}$ to give a white fluffy powder (4) $(41.8 \mathrm{mg}, 24 \%$, purity $>97 \%)$. MALDI-TOF MS (m/z): Calc. mass $[\mathrm{M}+\mathrm{H}]^{+}:$: 1604.7, found mass $[\mathrm{M}+\mathrm{H}]^{+}:$1604.6. FT-IR: $v\left(\mathrm{~cm}^{-1}\right)$ 3022; 2926; 2868; 2112; 1668; 1201; 1127; 1107; 698.

\section{Liposome Formulation}

Liposomes exposing $1 \mathrm{~mol} \%$ of the reactive cyclooctyne (5), the NTA affinity tag (6) or both were prepared with an overall PEGylation density of $5 \mathrm{~mol} \%$. The functionalized liposomes composed of DSPC/DSPE$\mathrm{PEG}_{2000} / \mathrm{DSPE}_{\mathrm{PEG}} \mathrm{P}_{200} \mathrm{R}$ (95:4:1) (R = cyclooctyne (5), NTA (6)) and DSPC/DSPE-PEG $2000 / \mathrm{DSPE}-$ $\mathrm{PEG}_{2000}$-cyclooctyne (5)/DSPE-PEG 2000 -NTA (6) (95:3:1:1) were prepared by the method described by Bangham et al. ${ }^{50}$. Lipids were dissolved in $\mathrm{CHCl}_{3}: \mathrm{CH}_{3} \mathrm{OH}(9: 1)$ and mixed in the desired ratios. The solvent was removed under a stream of nitrogen, and the lipid films placed under vacuum overnight to remove remaining traces of organic solvent. The obtained films were hydrated in tris(hydroxymethyl)-aminomethane (TRIS)/HCl buffer (100 mM, pH 8$)$ at $65^{\circ} \mathrm{C}$ for $1 \mathrm{~h}$ and vortexed every $10 \mathrm{~min}$ followed by 10 freeze-thaw cycles to form multilamellar liposomes. Unilamellar liposomes of approximately $100 \mathrm{~nm}$ in size were prepared by extrusion (Avanti ${ }^{\circledR}$ Mini-Extruder) of the multilamellar liposome suspension 21 times through a $100 \mathrm{~nm}$ polycarbonate filter (Nuclepore ${ }^{\circledR}$ ) at $65{ }^{\circ} \mathrm{C}$. The resulting unilamellar liposomes were stored at $5{ }^{\circ} \mathrm{C}$ until usage. The Ni-NTA-complex was initiated by addition of $\mathrm{NiCl}_{2}\left(1\right.$ or 10 equiv. in $\left.\mathrm{H}_{2} \mathrm{O}\right)$, followed by 2 h incubation. ${ }^{34}$ 


\section{Liposome Characterization}

The hydrodynamic diameter of the formed liposomes was analyzed by DLS and their $\zeta$-potentials measured using a Brookhaven Zeta PALS analyzer. Buffer: Sterile TRIS/HCl buffer (100 mM, pH 8). Dilution factor: 500. Number of runs: 10 runs per analysis. All liposomes were in the $110 \mathrm{~nm}$ range and all $\zeta$-potentials were slightly negative. The lipid concentration after extrusion was determined by measuring the phosphor content by ICP-MS and the overall liposome concentration adjusted accordingly.

\section{Post-functionalization of Liposomes}

Preformed functionalized liposomes $(25 \mathrm{mM}, 500 \mu \mathrm{L}$ or $5 \mathrm{mM}, 1000 \mu \mathrm{L})$ were mixed with $4(15 \mu \mathrm{L}$ in $\mathrm{CH}_{3} \mathrm{OH}, 0.5$ equiv.) giving an overall ligand concentration of $67 \mu \mathrm{M}$ and $13 \mu \mathrm{M}$. The reactions were shaken at $\mathrm{rt}$ and aliquots ( $40 \mu \mathrm{L}$ or $100 \mu \mathrm{L})$ were removed at specific time intervals for analysis by analytical HPLC. Sample aliquots were stored at $-80^{\circ} \mathrm{C}$ to quench the functionalization prior to HPLC analysis. The coupling efficiency was monitored by analytical HPLC employing a Waters XTerra ${ }^{\circledR} \mathrm{C}_{8} 5 \mu \mathrm{m}(4.6 \mathrm{x} 150 \mathrm{~mm})$ column or Waters XBridge ${ }^{\mathrm{TM}} \mathrm{C}_{18} 3.5 \mu \mathrm{m}(2.1 \times 50 \mathrm{~mm})$. Eluent: (A) $5 \% \mathrm{CH}_{3} \mathrm{CN}+0.1 \%$ TFA in $\mathrm{H}_{2} \mathrm{O}$, (B) $0.1 \%$ TFA in $\mathrm{CH}_{3} \mathrm{CN}$. Gradient profile: Linear gradient from $0 \% \mathrm{~B}$ to $100 \%$ B over 20 min. Flow rate: 1.0 $\mathrm{mL} / \mathrm{min}$. The coupling efficiency was calculated based on the area under the curve (AUC) for $\mathbf{4}$ and the DSPE-PEG $_{2000}$ conjugated product by using UV/VIS-detection at $220 \mathrm{~nm}$.

\section{AUTHOR INFORMATION}

\section{Corresponding Author}

*E-mail: Thomas.andresen@,nanotech.dtu.dk

\section{Notes}

The authors declare no competing financial interest. 


\section{ACKNOWLEDGEMENT}

2 The authors acknowledge financial support provided by the Technical University of Denmark (DTU) and the 3 Lundbeck Foundation.

\section{ABBREVIATIONS}

6 AUC, Area Under the Curve; DLS, Dynamic Light Scattering; DSPC, 1,2-distearoyl-sn-glycero-3-

7 phosphocholine; DSPE, 1,2-distearoyl-sn-glycero-3-phosphoethanolamine; EPR, Enhanced Permeability and 8 Retention; HPLC, High-Performance Liquid Chromatography; ICP-MS, Inductively Coupled Plasma Mass 9 Spectrometry; MALDI-TOF MS, Matrix-Assisted Laser Desorption/Ionization Time-Of-Flight Mass 10 Spectrometry; NTA, Nitrilotriacetic Acid; SPAAC, Strain Promoted Azide-Alkyne [3+2] Cycloaddition; 11 SPPS, Solid Phase Peptide Synthesis; TATE, $\left[\mathrm{Tyr}^{3}, \mathrm{Thr}^{8}\right]$-octreotate. 


\section{REFERENCES}

(1) Malam, Y., Loizidou, M., and Seifalian, A. M. (2009) Liposomes and nanoparticles: Nanosized vehicles for drug delivery in cancer. Trends Pharmacol. Sci. 30, 592-9.

(2) Kaasgaard, T., and Andresen, T. L. (2010) Liposomal cancer therapy: exploiting tumor characteristics. Expert Opin. Drug Deliv. 7, 225-43.

(3) Sapra, P., and Allen, T. M. (2003) Ligand-targeted liposomal anticancer drugs. Prog. Lipid Res. 42, 439462.

(4) Peer, D., Karp, J. M., Hong, S., Farokhzad, O. C., Margalit, R., and Langer, R. (2007) Nanocarriers as an emerging platform for cancer therapy. Nat. Nanotechnol. 2, 751-60.

(5) Maeda, H., Nakamura, H., and Fang, J. (2013) The EPR effect for macromolecular drug delivery to solid tumors: Improvement of tumor uptake, lowering of systemic toxicity, and distinct tumor imaging in vivo. Adv. Drug Deliv. Rev. 65, 71-9.

(6) Jølck, R. I., Feldborg, L. N., Andersen, S., Moghimi, S. M., and Andresen, T. L. (2010) Engineering Liposomes and Nanoparticles for Biological Targeting, in Biofunctionalization of Polymers and their Applications, pp 251-281.

(7) Shieh, P., and Bertozzi, C. R. (2014) Design strategies for bioorthogonal smart probes. Org. Biomol. Chem. 12, 9307-9320.

(8) Lallana, E., Sousa-Herves, A., Fernandez-Trillo, F., Riguera, R., and Fernandez-Megia, E. (2012) Click chemistry for drug delivery nanosystems. Pharm. Res. 29, 1-34.

(9) Chikh, G. G., Li, W. M., Schutze-Redelmeier, M.-P., Meunier, J.-C., and Bally, M. B. (2002) Attaching histidine-tagged peptides and proteins to lipid-based carriers through use of metal-ion-chelating lipids. Biochim. Biophys. Acta 1567, 204-12.

(10) Terpe, K. (2003) Overview of tag protein fusions: from molecular and biochemical fundamentals to commercial systems. Appl. Microbiol. Biotechnol. 60, 523-33.

(11) Algar, W. R., Prasuhn, D. E., Stewart, M. H., Jennings, T. L., Blanco-Canosa, J. B., Dawson, P. E., and Medintz, I. L. (2011) The controlled display of biomolecules on nanoparticles: A challenge suited to bioorthogonal chemistry. Bioconjug. Chem. 22, 825-58.

(12) Tornøe, C. W., Christensen, C., and Meldal, M. (2002) Peptidotriazoles on solid phase: [1,2,3]-Triazoles by regiospecific copper(I)-catalyzed 1,3-dipolar cycloadditions of terminal alkynes to azides. J. Org. Chem. $67,3057-64$.

(13) Rostovtsev, V. V., Green, L. G., Fokin, V. V., and Sharpless, K. B. (2002) A stepwise huisgen cycloaddition process: Copper(I)-catalyzed regioselective "ligation" of azides and terminal alkynes. Angew. Chem. Int. Ed. Engl. 41, 2596-9.

(14) Fournier, D., Hoogenboom, R., and Schubert, U. S. (2007) Clicking polymers: a straightforward approach to novel macromolecular architectures. Chem. Soc. Rev. 36, 1369-80.

(15) Hein, J. E., and Fokin, V. V. (2010) Copper-catalyzed azide-alkyne cycloaddition (CuAAC) and beyond: new reactivity of copper(I) acetylides. Chem. Soc. Rev. 39, 1302-15.

(16) Mamidyala, S. K., and Finn, M. G. (2010) In situ click chemistry: probing the binding landscapes of biological molecules. Chem. Soc. Rev. 39, 1252-61.

(17) Gaetke, L. (2003) Copper toxicity, oxidative stress, and antioxidant nutrients. Toxicology 189, 147-163.

(18) Burrows, C. J., and Muller, J. G. (1998) Oxidative Nucleobase Modifications Leading to Strand Scission. Chem. Rev. 98, 1109-1152. 
(19) Gierlich, J., Burley, G. A., Gramlich, P. M. E., Hammond, D. M., and Carell, T. (2006) Click chemistry as a reliable method for the high-density postsynthetic functionalization of alkyne-modified DNA. Org. Lett. $8,3639-42$.

(20) Wang, Q., Chan, T. R., Hilgraf, R., Fokin, V. V, Sharpless, K. B., and Finn, M. G. (2003) Bioconjugation by copper(I)-catalyzed azide-alkyne [3 + 2] cycloaddition. J. Am. Chem. Soc. 125, 3192-3.

(21) Agard, N. J., Prescher, J. A., and Bertozzi, C. R. (2004) A strain-promoted [3 + 2] azide-alkyne cycloaddition for covalent modification of biomolecules in living systems. J. Am. Chem. Soc. 126, 15046-7.

(22) Li, Z., Seo, T. S., and Ju, J. (2004) 1,3-Dipolar cycloaddition of azides with electron-deficient alkynes under mild condition in water. Tetrahedron Lett. 45, 3143-3146.

(23) Bernardin, A., Cazet, A., Guyon, L., Delannoy, P., Vinet, F., Bonnaffé, D., and Texier, I. (2010) Copper-free click chemistry for highly luminescent quantum dot conjugates: application to in vivo metabolic imaging. Bioconjug. Chem. 21, 583-8.

(24) Jølck, R. I., Sun, H., Berg, R. H., and Andresen, T. L. (2011) Catalyst-free conjugation and in situ quantification of nanoparticle ligand surface density using fluorogenic $\mathrm{Cu}$-free Click chemistry. Chem. - $A$ Eur. J. 17, 3326-3331.

(25) Bostic, H. E., Smith, M. D., Poloukhtine, A. A., Popik, V. V., and Best, M. D. (2012) Membrane labeling and immobilization via copper-free click chemistry. Chem. Commun. 48, 1431-1433.

(26) Oude Blenke, E., Klaasse, G., Merten, H., Plückthun, A., Mastrobattista, E., and Martin, N. I. (2015) Liposome functionalization with copper-free "click chemistry." J. Control. Release 202, 14-20.

(27) Fernández-Suárez, M., Baruah, H., Martínez-Hernández, L., Xie, K. T., Baskin, J. M., Bertozzi, C. R., and Ting, A. Y. (2007) Redirecting lipoic acid ligase for cell surface protein labeling with small-molecule probes. Nat. Biotechnol. 25, 1483-7.

(28) Link, A. J., Vink, M. K. S., Agard, N. J., Prescher, J. A., Bertozzi, C. R., and Tirrell, D. A. (2006) Discovery of aminoacyl-tRNA synthetase activity through cell-surface display of noncanonical amino acids. Proc. Natl. Acad. Sci. U. S. A. 103, 10180-5.

(29) Laughlin, S. T., Baskin, J. M., Amacher, S. L., and Bertozzi, C. R. (2008) In vivo imaging of membrane-associated glycans in developing zebrafish. Science 320, 664-7.

(30) Poloukhtine, A. A., Mbua, N. E., Wolfert, M. A., Boons, G.-J., and Popik, V. V. (2009) Selective labeling of living cells by a photo-triggered click reaction. J. Am. Chem. Soc. 131, 15769-76.

(31) Chang, P. V, Prescher, J. A., Sletten, E. M., Baskin, J. M., Miller, I. A., Agard, N. J., Lo, A., and Bertozzi, C. R. (2010) Copper-free click chemistry in living animals. Proc. Natl. Acad. Sci. U. S. A. 107, $1821-6$

(32) Feldborg, L. N., Jølck, R. I., and Andresen, T. L. (2012) Quantitative evaluation of bioorthogonal chemistries for surface functionalization of nanoparticles. Bioconjug. Chem. 23, 2444-50.

(33) Rüger, R., Müller, D., Fahr, A., and Kontermann, R. E. (2005) Generation of immunoliposomes using recombinant single-chain Fv fragments bound to Ni-NTA-liposomes. J. Drug Target. 13, 399-406.

(34) Dietrich, C., Schmitt, L., and Tampé, R. (1995) Molecular organization of histidine-tagged biomolecules at self-assembled lipid interfaces using a novel class of chelator lipids. Proc. Natl. Acad. Sci. U. S. A. 92, 9014-8.

(35) Rüger, R., Müller, D., Fahr, A., and Kontermann, R. E. (2006) In vitro characterization of binding and stability of single-chain Fv Ni-NTA-liposomes. J. Drug Target. 14, 576-82.

(36) Dong, X.-Y., Feng, X.-D., and Sun, Y. (2010) His-tagged protein purification by metal-chelate affinity extraction with nickel-chelate reverse micelles. Biotechnol. Prog. 26, 1088-94. 
(37) Knecht, S., Ricklin, D., Eberle, A. N., and Ernst, B. (2009) Oligohis-tags: mechanisms of binding to Ni2+-NTA surfaces. J. Mol. Recognit. 22, 270-9.

(38) Lata, S., Reichel, A., Brock, R., Tampé, R., and Piehler, J. (2005) High-affinity adaptors for switchable recognition of histidine-tagged proteins. J. Am. Chem. Soc. 127, 10205-15.

(39) Tanner, P., Ezhevskaya, M., Nehring, R., Van Doorslaer, S., Meier, W., and Palivan, C. (2012) Specific His6-tag attachment to metal-functionalized polymersomes relies on molecular recognition. J. Phys. Chem. B $116,10113-24$.

(40) Platt, V., Huang, Z., Cao, L., Tiffany, M., Riviere, K., and Szoka, F. C. (2010) Influence of multivalent nitrilotriacetic acid lipid-ligand affinity on the circulation half-life in mice of a liposome-attached His6protein. Bioconjug. Chem. 21, 892-902.

(41) McCusker, C. F., Kocienski, P. J., Boyle, F. T., and Schätzlein, A. G. (2002) Solid-phase synthesis of c(RGDfK) derivatives: on-resin cyclisation and lysine functionalisation. Bioorg. Med. Chem. Lett. 12, 547-9.

(42) Budyka, M. F. (2008) Photodissociation of aromatic azides. Russ. Chem. Rev. 77, 709-723.

(43) Schultz, M. K., Parameswarappa, S. G., and Pigge, F. C. (2010) Synthesis of a DOTA-biotin conjugate for radionuclide chelation via $\mathrm{Cu}$-free click chemistry. Org. Lett. 12, 2398-2401.

(44) Pack, D. W., and Arnold, F. H. (1997) Langmuir monolayer characterization of metal chelating lipids for protein targeting to membranes. Chem. Phys. Lipids 86, 135-52.

(45) Nieba, L., Nieba-Axmann, S. E., Persson, A., Hämäläinen, M., Edebratt, F., Hansson, A., Lidholm, J., Magnusson, K., Karlsson, A. F., and Plückthun, A. (1997) BIACORE analysis of histidine-tagged proteins using a chelating NTA sensor chip. Anal. Biochem. 252, 217-228.

(46) Smith, R. M., Martell, A. E., and Motekaitis, R. J. (2004) NIST Standard Reference Database 46 1-20.

(47) Hochuli, E., Döbeli, H., and Schacher, A. (1987) New metal chelate adsorbent selective for proteins and peptides containing neighbouring histidine residues. J. Chromatogr. A 411, 177-184.

(48) Crowe, J., Döbeli, H., Gentz, R., Hochuli, E., Stüber, D., and Henco, K. (1994) 6xHis-Ni-NTA chromatography as a superior technique in recombinant protein expression/purification. Methods Mol. Biol. 31, 371-87.

(49) Thieriet, N., Giralt, E., Guib, F., and Albericio, F. (1997) Use of Alloc-amino Acids in Solid-Phase Peptide Synthesis . Tandem Deprotection-Coupling Reactions Using Neutral Conditions. Tetrahedron Lett. $38,7275-7278$.

(50) Bangham, A. D., and Horne, R. W. (1964) Negative staining of phospholipids and their structural modification by surface-active agents as observed in the electron microscope. J. Mol. Biol. 8, 660-668. 


\section{Table of Contents Artwork}

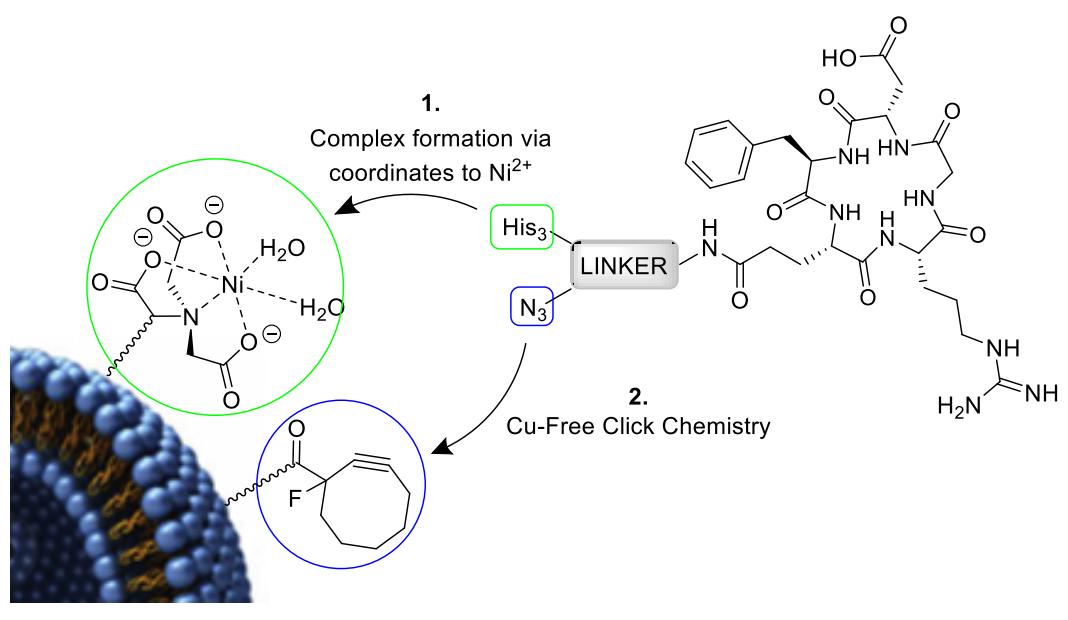

3

4

5 